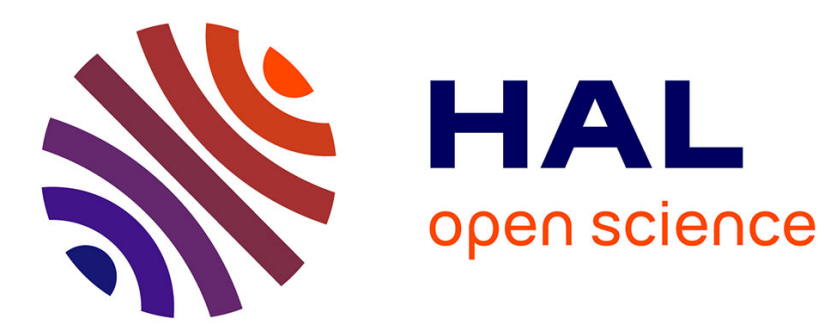

\title{
Economic Evaluation of Enhanced Oil Recovery
}

A. Zekri, K. K. Jerbi

\section{To cite this version:}

A. Zekri, K. K. Jerbi. Economic Evaluation of Enhanced Oil Recovery. Oil \& Gas Science and Technology - Revue d'IFP Energies nouvelles, 2002, 57 (3), pp.259-267. 10.2516/ogst:2002018 . hal02043944

\section{HAL Id: hal-02043944 \\ https://hal.science/hal-02043944}

Submitted on 21 Feb 2019

HAL is a multi-disciplinary open access archive for the deposit and dissemination of scientific research documents, whether they are published or not. The documents may come from teaching and research institutions in France or abroad, or from public or private research centers.
L'archive ouverte pluridisciplinaire HAL, est destinée au dépôt et à la diffusion de documents scientifiques de niveau recherche, publiés ou non, émanant des établissements d'enseignement et de recherche français ou étrangers, des laboratoires publics ou privés. 


\title{
Economic Evaluation of Enhanced Oil Recovery
}

\author{
A.Y. Zekri ${ }^{*}$ and K.K. Jerbi ${ }^{2}$ \\ 1 United Arab Emirates University \\ 2 Waha Oil Co \\ e-mail: <a.zekri@uaeu.ac.ae> \\ * Corresponding author
}

\begin{abstract}
Résumé - Évaluation économique de la récupération assistée du pétrole — La recherche de nouveaux gisements d'hydrocarbures a engendré le développement de nouvelles approches qui dépassent les stratégies conventionnelles d'exploration et de production. Ce type d'approche, couramment désigné « récupération assistée des hydrocarbures», recouvre un ensemble de technologies impliquant l'utilisation, par exemple, d'outils thermiques et chimiques pour produire plus d'hydrocarbures. Les résultats d'une application réussie de cette technologie auront un impact décisif sur les programmes de conservation d'énergie pour tout pays producteur de pétrole.
\end{abstract}

Souvent, un plan national énergétique est compliqué et représente d'énormes défis lors de sa mise en place. Un programme cohérent et complet doit prendre en considération toutes les options possibles. Un des objectifs de la Libye est de produire davantage d'hydrocarbures, c'est-à-dire, d'accroître la récupération assistée des champs pétroliers. La mise en place d'un tel projet nécessite une attention particulière à de nombreux problèmes, qui se traduisent par d'énormes délais pour les études, l'évaluation, la conception et surtout l'impact économique du projet de récupération.

Cette étude a pour but de présenter une analyse économique d'un champ pétrolier, qui constitue l'un des supports les plus prometteurs à l'application des techniques de récupération. En effectuant une analyse de sensibilité économique sur les principaux paramètres tels que le prix du brut, le prix des solvants injectés, les coûts d'investissement et d'opération ainsi que la récupération du brut, on peut produire des courbes d'analyse de sensibilité pour chaque paramètre. Ainsi, il est possible d'évaluer toute planification par rapport au coût économique des projets de récupération assistée en Libye. L'optimisation économique est le but ultime de la gestion des gisements.

Avec des données concernant la production, l'investissement, les coûts d'opération et le coût financier, la viabilité des projets est évaluée. Les résultats de cette étude peuvent servir à tout projet de récupération, n'importe où dans le monde.

\footnotetext{
Abstract - Economic Evaluation of Enhanced Oil Recovery - The research for tomorrow's oil reserves has directed the efforts of the energy industry to frontiers beyond the conventional exploration and production strategies. These frontiers are defined not by geography or geology but rather by technology. They are a collection of technologies-involving the use of thermal, gas and chemical means for producing more oil-that fall under the broad umbrella called Enhanced Oil Recovery (EOR). The results of successful application of this new technology will have a decisive impact on the energy conservation program of any oil producing country. A comprehensive national energy program is complex and to plan it represents a challenge. A unified and complete national program must encompass
} 
the consideration of all possible options. The potential of each need to be explored. One such option in Libya is to produce more oil, that is, to effect the enhancement of oil recovery from the nation oil fields. The planning of an EOR project demands a meticulous attention to many problems, thus requiring considerable lead time for studies, evaluations, project design and, most of all, the economics of these high cost EOR projects.

The objective of this study is to conduct an economic analysis on one of the most representative candidate major field in Libya ( $D$ field) for application of the technically approved enhanced oil recovery methods. By performing economic sensitivity analysis on key input variables such as oil prices, the price of injection solvent, capital expenditures, operating expenses, and oil recovery, the aim is to develop sensitivity analysis graphs for each variable to assess future engineering planning with regard to the EOR projects economics in Libya. Economic optimization is the ultimate goal of reservoir engineering management. With estimated production, capital, operating expenses, and financial data, project economics are evaluated. Project finding could be applied to any EOR candidate reservoir worldwide.

\section{INTRODUCTION}

At present, the world-wide production statistics indicate that the average ultimate recovery from light and medium gravity oils by conventional (primary/secondary) methods is around $25-35 \%$ of the Original Oil in Place (OOIP), while from heavy oil deposits on the average, only $10 \%$ OOIP is recoverable. Hence leaving substantial percentage of oil in place non-recoverable by the conventional methods and these reaming reserves are the target of the EOR to increase the recovery percentage.

Limited work has been published regarding the economics of EOR projects. Bordor (1992) demonstrated how economic analysis can be used to determine the most effective direction for research. He concluded that economic analysis gives guidance to determine whether there are fundamental limitations to the process which preclude development of a practical process. Flanders et al. (1993) investigated the economic viability of conducting $\mathrm{CO}_{2}$ EOR operation in small to medium-size fields. They concluded that EOR tax incentive reduces the risk of undertaken a $\mathrm{CO}_{2}$ project and economic viability of $\mathrm{CO}_{2} \mathrm{EOR}$ is very field-specific.

The volume of reserves already discovered and the size of the sedimentary limit the extent to which reserves can be increased by enhanced recovery schemes. As exploratory prospects become depleted and new discoveries more scarcely, the importance of increasing reserves through recovery of a higher fraction of the oil in place by means of EOR is correspondingly increased. Preliminary EOR studies indicate that the additional of oil reserves attributable to enhanced recovery schemes in Libyan oil reservoirs are significant, and thus the economics of these schemes are important. Results of studies show that many Libya reservoirs lend themselves to the application of several EOR methods. No matter what method is to be applied, injectant availability, suitability and requirement and economic feasibility must be considered early in the planning and design of an EOR project.
Our preliminary investigations indicated that the techniques of EOR chemical process are not cost-effective because of the logistics of supplying large volumes of chemicals such as polymers, surfactants, alkaline solutions, etc., to most field locations. Thermal processes are considered only for the Haram field (heavy oil) but eliminated from further consideration in other fields because the depth and pressures of these reservoirs make the processes economically unattractive for light oil reservoirs. Data from many reservoir studies indicate that gas injection processes may be technically feasible. Consequently, our current development and application of EOR technologies in Libya will be limited to miscible flood schemes by hydrocarbons ( $\mathrm{HC})$ and $\mathrm{CO}_{2}$ gases. The gas injection processes which are under consideration in Libya reservoirs include the following: hydrocarbon miscible flooding processes, miscible and immiscible $\mathrm{CO}_{2}$ flooding.

From all-Libyan EOR candidate reservoirs, D reservoir was selected as field representative model to conduct the EOR economic analysis due to the following reasons:

- it has the most complete technical data needed for EOR economic analysis;

- it is one of Libya largest reservoirs with the most conventional for EOR oil;

- it is the easiest one to tackle with existing technology.

\section{EOR ECONOMIC MODEL}

An economic model should evaluate various production strategy schemes. As predication of future market trends is nearly a crystal ball game, then we should make predication under diverse economic scenarios to get a good feel for the sensitivity of the expected net revenues to the vagaries of the market. Economic models have been designed to simulate the development and operation of actual EOR projects. The characteristics of the reservoir and the costs of producing 
EOR oil in that reservoir are entered into the model, which then generate estimate of:

- the quantity of crude oil that will be produced from the project;

- a price sufficient to reimburse all costs of the project and provide an adequate Return On Investment (ROI);

- the timing at which reserves in the reservoir will be produced.

These estimates are then aggregated for the overall estimates of daily production, cumulative production, and ultimate recovery.

\subsection{General Structure of the Economic Model}

The estimate of the amount to be recovered through EOR application is based on actual reservoir parameters of oil saturation, pore volume and previous primary and secondary recovery, and the actual recovery calculation differs among techniques. This estimate is displayed as total incremental EOR production and incremental production per year from the time the project was initiated. The oil recoveries obtained by using compositional reservoir simulation model. The estimate of price is based on the projection of cash flows and a set rate of return. Cash inflows are generated by the production of oil. Cash outflow are comprised the following investment and operating costs: field development expenditures, equipment expenditures, operating and maintenance costs, injection material costs and other costs.

The cash flows are expressed as dollars per year from the time of project initiation. They are based on development characteristics, numerous technique specific and general costs parameters, and several assumptions, all of which are discussed later. The production estimate is matched with investment and operating costs and various rates of return to calculate the required price for the oil. Conversely, the models compute the rate of return yielded at series of fixed prices. The quantities of oil are aggregated by price to construct the price-supply curves. Individual price-supply curves for each technique and an overall price-supply curve for EOR recovery are generated. Based on selected prices and development assumption, these price-supply curves are converted to the timing at which reserves become proved and are produced. These curves are then extrapolated based on remaining oil in place and then the aggregated quantities of oil are aggregated by price to construct the price-supply curves.

\subsection{EOR Recovery and Risk Assumptions}

In EOR recovery, only a small portion of failures is complete technical failures where no additional oil is recovered. Rather, the failures are generally economic failures where the recovery was insufficient, too slow, or too costly in relation to the price of oil. Three considerations have been incorporated into the model which account for technical risk:

- The recovery model has been empirically constructed from actual field experiences; thus, the specific recovery parameters represent an average of marginal and highly successful projects.

- The screening guide used for selecting reservoirs favorable to EOR has eliminated the least favorable reservoirs (e.g., the ones with the highest technical risk) and has assigned the remaining reservoirs to the most favorable technique; therefore, some of the failure risks have been mitigated.

- The economic model incorporates a consideration for technical failures using an approach analogous to the allocation of dry hole costs to successful wells.

While EOR projects are considered risky and carry a higher target rate of return, an analysis indicates that the economic effects of risk and failure may be lower than generally perceived. These effects stem from the reservoir development practices used for EOR recovery, which serves to minimize the total of capital at risk. Typically, companies initiate a pilot project prior to full reservoir development. Therefore, actual investment losses can be held to the costs of the pilots, minimizing the risks of reservoir wide failure.

The risk premium can be calculated based on the following two equations:

(Investment cost per acre for the pilot $) \times($ Pilot acreage $)$ $\times$ (probability of failure)

and,

(Investment cost per acre) $\times($ full EOR acre $)$

$$
\times(1 \text { - probability of failure })
$$

The actual risk premium for any particular reservoir could, of course, vary widely from this hypothetical case.

\subsection{Financial Assumption}

The model incorporate a series of financial assumptions that affect the price estimates such as the following:

- Date of cost assessment. The costs used are assumed to be applicable as of the date of initiating the project. As these model is used in future years, the specific cost parameters will need to be updated to reflect cost changes.

- Sharing of costs. The model assumes that well operating costs are shared between primary/secondary and EOR production. For this assumption, a primary/secondary production decline curve was constructed for each reservoir.

- Allocation of general and administrative (G\&A) overhead costs. Enhanced recovery projects place increased burden on the administration of a company in both field and headquarter operation. Producing companies reflect the costs of this burden by adding an amount to the costs of 
the project for G\&A or overhead costs. Based on the practices of numerous producing companies, the model assumes project G\&A cost per year equal to the following: $20 \%$ of basic and incremental injection operating and maintenance costs plus $4 \%$ of investment costs.

- Distribution of tangible and intangible costs for drilling and completion. Producing companies use a variety of accounting principles for the costs for drilling and completing wells. Selection of these principles affects reported profits and tax liability. Central to these issues is the differentiation of tangible (capitalized) from intangible (expensed) costs. The model assumes that the company uses a successful efforts approach (e.g., expenses all intangible costs) for its tax deduction. As a result, the following rules apply:

- Intangible costs equal to $70 \%$ of drilling and completion cost for production wells and $100 \%$ of workover costs are expended in the year incurred.

- Tangible costs equal to $30 \%$ of drilling and completion costs for production wells, plus $100 \%$ of all other well lease, and injection investment costs are expended (through depreciation) based on a unit of production approach.

TABLE 1

Cost elements of EOR miscible projects

\begin{tabular}{|c|c|c|}
\hline COST ELEMENTS & EXPLANATION OF COST ELEMENTS & COST DETERMINATION \\
\hline \multicolumn{3}{|l|}{ Field development expenditures } \\
\hline Drilling and completion & $\begin{array}{l}\text { Drill sufficient new production wells to provide the } \\
\text { required acre spacing; drill sufficient injection wells } \\
\text { to provide the injection pattern. }\end{array}$ & $\begin{array}{l}\text { Number of new production and injection wells } \\
\text { drilled; costs vary by depth and region. }\end{array}$ \\
\hline Workover and conversion & $\begin{array}{l}\text { Bring existing production and injection wells to } \\
\text { acceptable quality. }\end{array}$ & $\begin{array}{l}\text { Number production and injection wells that need } \\
\text { workover; variable by age of latest field } \\
\text { development costs vary by depth and region. }\end{array}$ \\
\hline \multicolumn{3}{|l|}{ Equipment expenditures } \\
\hline $\begin{array}{l}\text { Well, lease, and field production } \\
\text { equipment }\end{array}$ & $\begin{array}{l}\text { Install equipment necessary to operate new } \\
\text { production wells. }\end{array}$ & $\begin{array}{l}\text { Number of new production wells drilled; costs } \\
\text { vary by depth and region. }\end{array}$ \\
\hline Injection equipment & $\begin{array}{l}\text { Install equipment necessary to operate new injection } \\
\text { wells. }\end{array}$ & $\begin{array}{l}\text { Number of new production and injection wells } \\
\text { drilled. Costs vary by depth and region. }\end{array}$ \\
\hline $\begin{array}{l}\text { Separation and compression } \\
\text { equipment }\end{array}$ & $\begin{array}{l}\text { Install sufficient equipment to produce maximum } \\
\text { yearly requirement for recycle indicants. }\end{array}$ & Maximum pore volume injection per year. \\
\hline \multicolumn{3}{|l|}{ Operating and maintenance costs } \\
\hline $\begin{array}{l}\text { Normal operating and maintenance } \\
\text { costs }\end{array}$ & $\begin{array}{l}\text { Cover normal daily operation, surface repair and } \\
\text { maintenance, and subsurface repair, maintenance and } \\
\text { services (include artificial lift of primary production). }\end{array}$ & $\begin{array}{l}\text { Normal production and injection wells. Costs } \\
\text { vary by depth and region. }\end{array}$ \\
\hline $\begin{array}{l}\text { Incremental injection operating and } \\
\text { maintenance costs }\end{array}$ & $\begin{array}{l}\text { Cover incremental operating and maintenance costs } \\
\text { due to injection operation and increased fluid } \\
\text { handling. }\end{array}$ & $\begin{array}{l}\text { Number and injection wells. Costs vary by depth } \\
\text { and region. }\end{array}$ \\
\hline \multicolumn{3}{|l|}{ Injection material costs } \\
\hline Purchased injacants & $\begin{array}{l}\text { Inject the specified reservoir pore volume of recycle } \\
\text { indicants over the determined time period. }\end{array}$ & $\begin{array}{l}\text { Amount of pore volume; cost of injacants } \\
\text { variable by source, purchased or recovered (see } \\
\text { unit costs for injacants miscible). }\end{array}$ \\
\hline Recycle injection fluids & $\begin{array}{l}\text { Inject reservoir pore volume of recovered injectant } \\
\text { from production (per injection schedule for recycle } \\
\text { injectant. }\end{array}$ & \\
\hline \multicolumn{3}{|l|}{ Other costs } \\
\hline $\begin{array}{l}\text { Field study, engineering, and } \\
\text { supervision }\end{array}$ & $\begin{array}{l}\text { Provide research, development, and management } \\
\text { support to the project. }\end{array}$ & Include in general and overhead costs. \\
\hline
\end{tabular}


TABLE 2

Incremental cost production

\begin{tabular}{|l|c|c|c|c|c|c|}
\hline \multirow{2}{*}{} & \multicolumn{2}{|c|}{ BASE CASE } & \multicolumn{2}{c|}{$\mathrm{CO}_{2}$ CASE } & \multicolumn{2}{c|}{ HC CASE } \\
\cline { 2 - 8 } & \multicolumn{2}{|c|}{ Incremental cost } & \multicolumn{2}{|c|}{ Incremental cost } & \multicolumn{2}{c|}{ Incremental cost } \\
\hline & $(\$ \mathrm{MM})$ & $(\$ / \mathrm{bbl})$ & $(\$ \mathrm{MM})$ & $(\$ / \mathrm{bbl})$ & $(\$ \mathrm{MM})$ & $(\$ / \mathrm{bbl})$ \\
\hline Opex & 2538 & 1.37 & 951 & 1.44 & 2942 & 1.38 \\
\hline $\mathrm{CO}_{2} / \mathrm{HC}$ purchase cost & 0 & 0.00 & 3570 & 5.41 & 24752 & 11.59 \\
\hline Capex & 0 & 0.00 & 190 & 0.29 & 190 & 0.09 \\
\hline Sub-total & 2538 & 1.37 & 4711 & 7.14 & 27884 & 13.06 \\
\hline Royalties & 8029 & 4.33 & 2864 & 4.34 & 9257 & 4.34 \\
\hline Taxes & 24439 & 13.19 & 6244 & 9.46 & 11953 & 5.60 \\
\hline Total costs & 35006 & & 13819 & & 49094 & \\
\hline Oil and cond. prod. (MMbbl) & 1853 & & 2513 & & 2988 & \\
\hline Incremental prod. (MMbbl) & 0 & & 660 & & 1135 & \\
\hline
\end{tabular}

\section{ECONOMIC ANALYSIS CASES}

Three cases to be evaluated were defined as following:

- Base case: continue production using conventional production process (primary and secondary).

- Carbon dioxides $\mathrm{CO}_{2}$ miscible case. Implementing EOR using $\mathrm{CO}_{2}$ injection.

- Hydrocarbon (HC) case. Implementing EOR using (HC) injection.

Table 1 presents cost elements of EOR miscible projects; meanwhile Table 2 presents incremental cost of production. The total capital cost is estimated to be some \$MM190 based on similar projects performed in the oil industry and further tuned to reflect the Libya fields was used for $\mathrm{CO}_{2}$ and $\mathrm{HC}$ EOR cases, this total estimate covers the following items:

- Drilling, completion, and tie-in costs for new wells (e.g. production wells, gas injection wells, water injection wells, source water wells, water disposal wells).

- Convert existing wells (e.g. produces to injectors and vice versa).

- Capital expenditures for new facilities (e.g. compression facilities for gas injection; high pressure distribution system for gas injection; separation, dehydration, and purification facilities to process produced gas for reinjection).

Operating cost was based on the average operating expense figures for "D" field over the period 1993-1999. These are the costs for conventional oil production and include field, pipeline, terminal and overhead expenses. Additional costs were included for the EOR processes, such as compression, injection and reprocessing of $\mathrm{CO}_{2} / \mathrm{HC}$ gas. Sensitivity analysis has been performed on operating expenses in order to compensate for any deviation in the future estimated operation cost due to EOR. Table 3 shows the financial and cost variables used in this study.

\section{TABLE 3}

Summary of financial and cost variables

\begin{tabular}{|c|c|}
\hline Variable & Value \\
\hline Oil price & $\$ 20 / \mathrm{bbl}$ \\
\hline Royalty & Gross income $\times 16.67$ \\
\hline Cost of $\mathrm{CO}_{2}$ injection & $\$ 5.41 / \mathrm{bbl}$ of oil \\
\hline Cost of $\mathrm{HC}$ injection & $\$ 11.59 / \mathrm{bbl}$ of oil \\
\hline $\begin{array}{l}\text { Deemed gross } \\
\text { income }\end{array}$ & $\begin{array}{l}\text { Oil price } \times \text { tax reference price } \\
\times \text { production } \\
(\text { tax reference price factor }=1 / 3)\end{array}$ \\
\hline Depreciation & Tangible capital investment/years \\
\hline Income tax & $\begin{array}{l}\text { (Deemed gross income - royalty - operating } \\
\text { cost - depreciation) } \times 0.65\end{array}$ \\
\hline Net cash flow & $\begin{array}{l}\text { Real gross income - capital investment } \\
\text { - royalty - operating cost - income tax }\end{array}$ \\
\hline $\begin{array}{l}\text { Conventional } \\
\text { operating cost }\end{array}$ & $\$ 1.37 / \mathrm{bbl}$ \\
\hline
\end{tabular}




\section{ECONOMIC RESULTS AND DISCUSSION}

Table 4 presents the pre-tax and after tax discounted cash flow results of the base case, $\mathrm{CO}_{2}$ case and $\mathrm{HC}$ case. The largest cost component in the $\mathrm{HC}$ solvent is the Natural Gas Liquid (NGL). The NGL cost represents approximately $80 \%$ of the total cost of the $\mathrm{HC}$ injection solvent. The after-tax results indicate that in the current economic climate, continued conventional production (i.e., base case) is more economical than enhanced oil recovery. Given the large EOR production potential, this means that adjustments will be required in key input variables (e.g., oil price, tax rate, EOR technology) in order to improve the viability of the EOR projects. The pre-tax results are much more positive for the EOR developments, although these results can vary dramatically with the cost of the injection gas. On both a pretax and after-tax basis, $\mathrm{CO}_{2}$ injection appears to be much more attractive than $\mathrm{HC}$ solvent injection. The large spread between the pre-tax and after-tax results indicates that tax incentives (i.e., tax reductions) will likely be required before an EOR project in D field can become economically viable on an after-tax basis. The situation is probably similar for a number of other fields that are EOR candidates. As a result, a special tax structure will likely be required for EOR project in general before many of them can proceed. The estimated capital and operating cost per barrel of incremental oil produced in as follows: $\mathrm{CO}_{2}$ injection is $\$ 7.14$ and $\mathrm{HC}$ injection is $\$ 13.06$. The economics of these projects will improve with: higher oil prices, improved EOR technology lower cost for gas injection, lower NGL requirements in the $\mathrm{HC}$ solvent, inclusion of gas revenues from production and sale of $\mathrm{CO} / \mathrm{HC}$ gas, adjustments to the tax structure (lower tax and royalty rates) and produced $\mathrm{CO}_{2} / \mathrm{HC}$ could be sold for reuse in other fields. If a respective gas production forecast could be provided, the economics for the EOR proposals could be improved by including the additional revenue from the sale of this gas.

\section{TABLE 4}

Discounted cash flow

\begin{tabular}{|l|c|c|}
\hline & $\begin{array}{c}\text { After-tax } \\
(\$ M M)\end{array}$ & $\begin{array}{c}\text { Pre-tax } \\
(\$ M M)\end{array}$ \\
\hline Base case & +754 & +9770 \\
\hline $\mathrm{CO}_{2}$ case & +554 & +13767 \\
\hline $\mathrm{HC}$ case & -1895 & +11673 \\
\hline
\end{tabular}

\subsection{EOR Economic Sensitivities}

Sensitivity analysis was performed on $\mathrm{CO}_{2} / \mathrm{HC}$ purchase price, oil price, operating expenses, tax rate, and royalty rate. The results are discussed in the following sections.

\subsubsection{Prices Sensitivity}

The price of oil must exceed $\$ 25 / \mathrm{bb} 1$ on an after-tax basis before $\mathrm{CO}_{2}$ injection becomes more economical than conventional production (Fig. 1). The incremental after-tax Net Present Value (NPV) for HC injection decrease as the price of oil increases. This is due to a corresponding increase in the cost of NGLs for injection. Meanwhile the $\mathrm{CO}_{2}$ price sensitivity analysis indicates $\mathrm{CO}_{2}$ must be priced at less than $\$ 0.50 /$ MSCF (Thousands of Standard Cubic Feet) on an after-tax basis before EOR with $\mathrm{CO}_{2}$ injection is more economical than conventional production (Fig. 2). HC solvent must be priced at less than $\$ 1.52 / \mathrm{MSCF}$ on an aftertax basis, or $\$ 7.80 / \mathrm{MSCF}$ on an pre-tax basis before EOR with HC solvent injection is more economical than conventional production (Fig. 2).

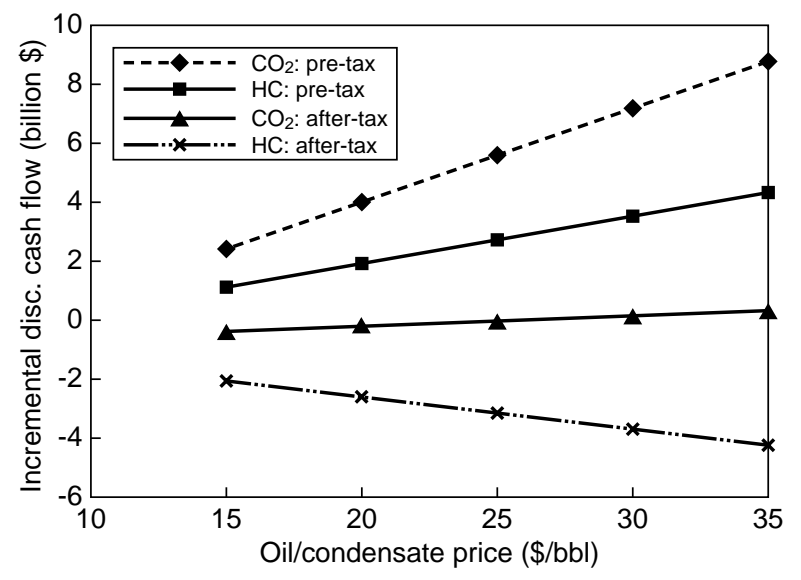

Figure 1

Oil price sensitivity.

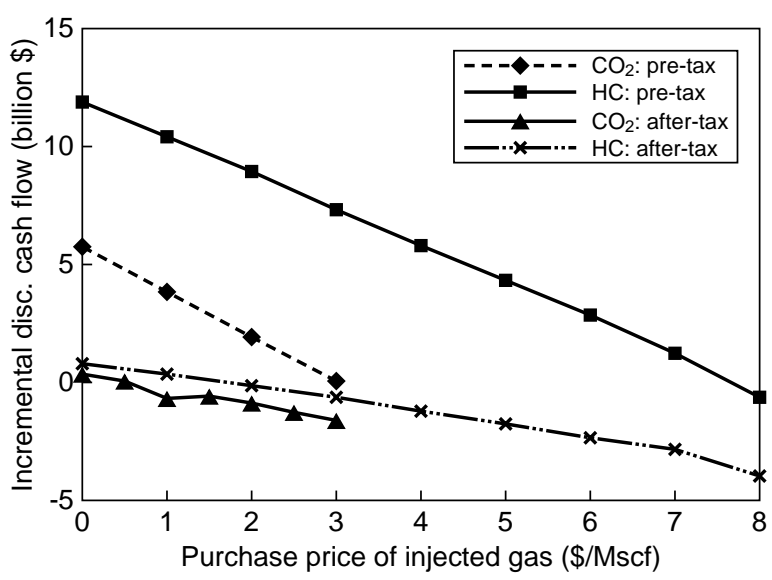

Figure 2

$\mathrm{CO}_{2} / \mathrm{HC}$ gas price sensitivity. 


\subsubsection{Operating Expense Sensitivity}

On an after-tax basis, the base case remains economical as operating expenses remain less than $\$ 4.50 / \mathrm{bb} 1$ (Fig 3). The comparable figure for $\mathrm{CO}_{2}$ injection is $\$ 2.75 / \mathrm{bbl}$. $\mathrm{HC}$ injection will remain uneconomical even if operating costs decrease to nil.

\subsubsection{Capital Spending and Tax Rate Sensitivity}

After-tax returns are negative for all levels of capital on EOR. Per-tax discounted cash flow is positive, but drops by $\$ 0.68$ for every additional dollar of capital spending (Fig. 4). Before EOR development economical on an after-tax basis, the tax rate must decrease from $65 \%$ to less than $60 \%$ for $\mathrm{CO}_{2}$ injection or less than $27 \%$ for $\mathrm{HC}$ solvent injection (Fig. 5).

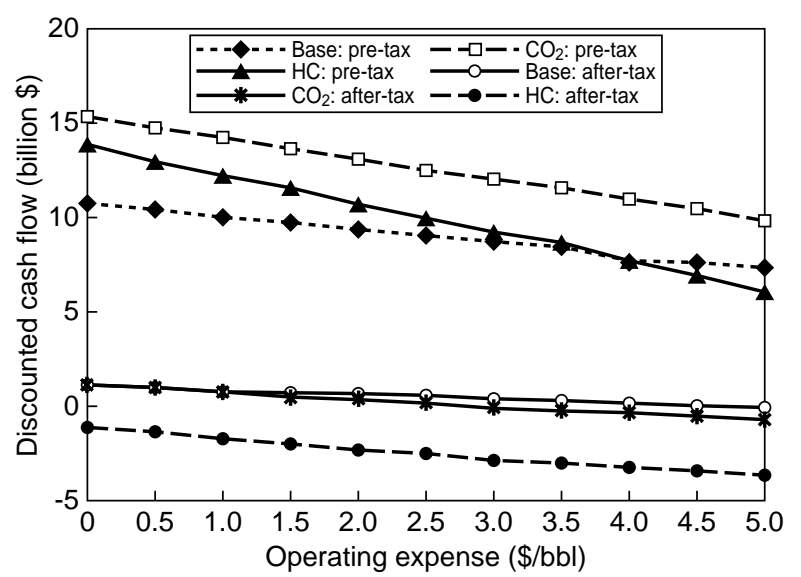

Figure 3

Operating expenses sensitivity.

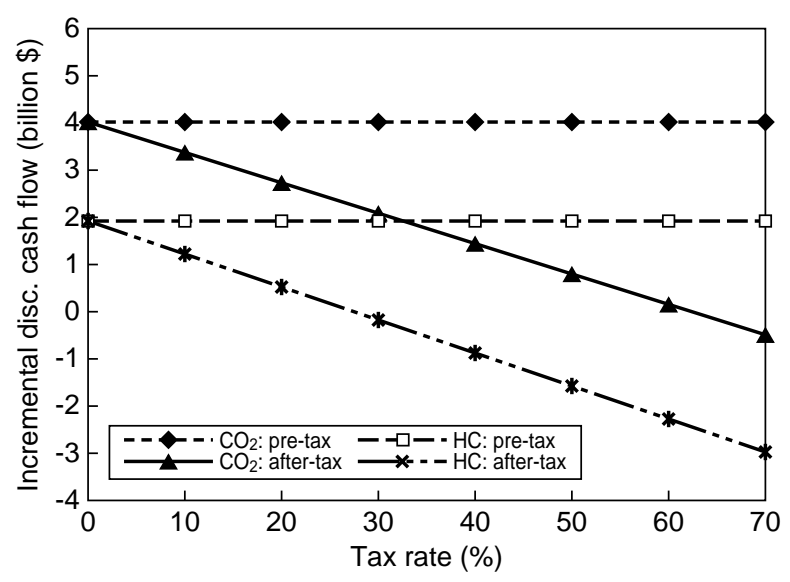

Figure 5

Tax rate sensitity.

\subsubsection{Royalty Rate and Inflation Sensitivity}

For $\mathrm{CO}_{2}$ injection, the royalty rate must decrease from $16.67 \%$ before the after-tax NPV of EOR development superior to that for conventional production processes (Fig. 6). HC solvent injection will remain uneconomical on an after-tax basis, even if the royalty rate is decreased to $0 \%$. On pre-tax basis, discounted cash flow for both $\mathrm{CO}_{2}$ and $\mathrm{HC}$ injection will improve as prices and costs increase over time (Fig. 7). On an after-tax basis, the NPV for $\mathrm{CO}_{2}$ injection will remain constant, while for $\mathrm{HC}$ injection the NPV will decrease.

\subsubsection{General Sensitivity Analysis}

A general curves to assess before and after tax for both $\mathrm{CO}_{2}$ and hydrocarbon gas injection were generated as shown in

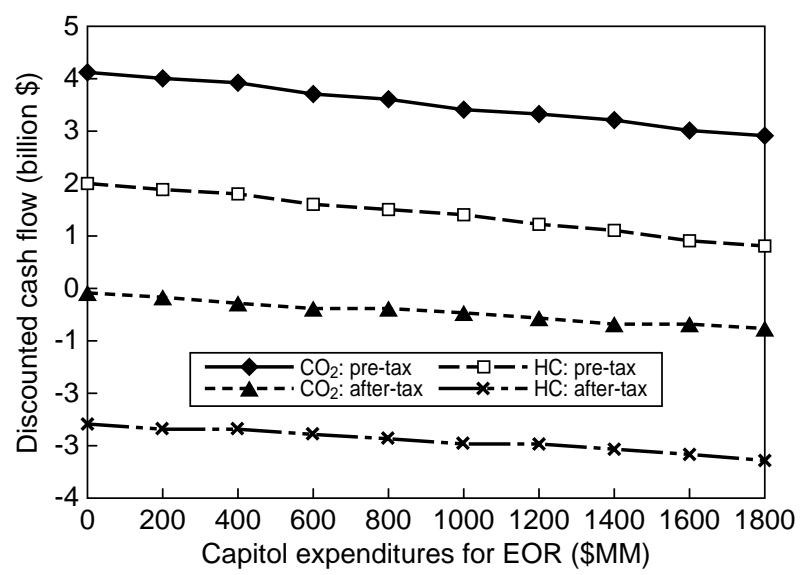

Figure 4

Capital spending sensitivity.

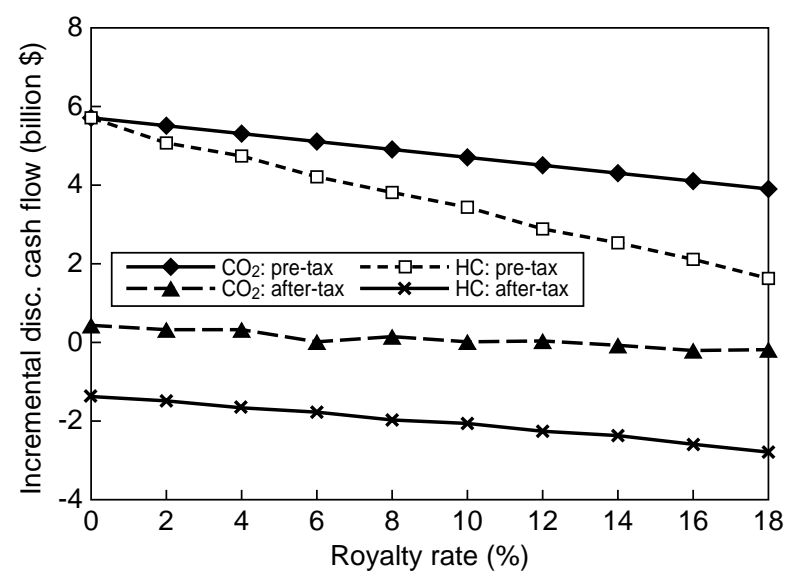

Figure 6

Royalty rate sensitivity. 


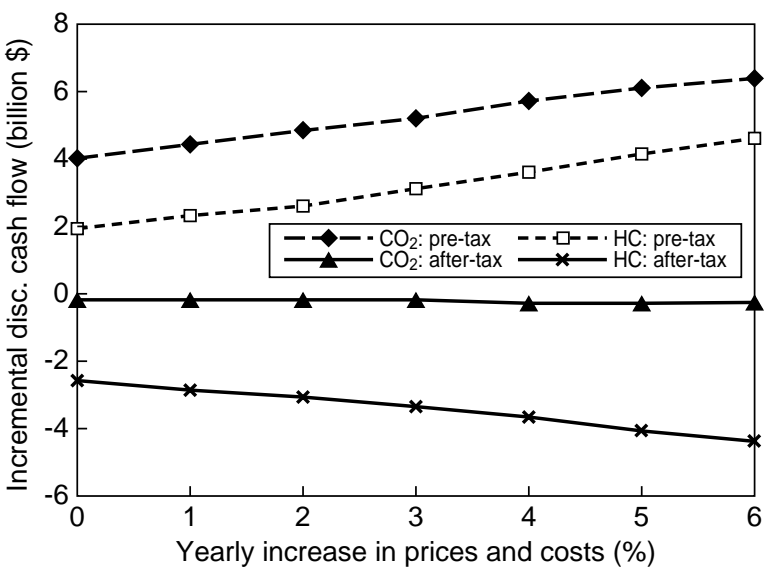

Figure 7

Inflation sensitivity.

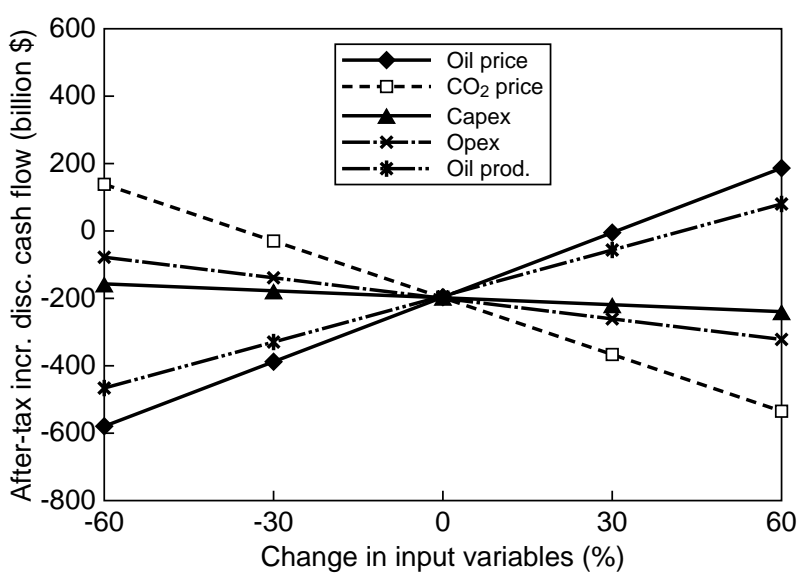

Figure 9

NPV sensitivity, after-tax, $\mathrm{CO}_{2}$ case.

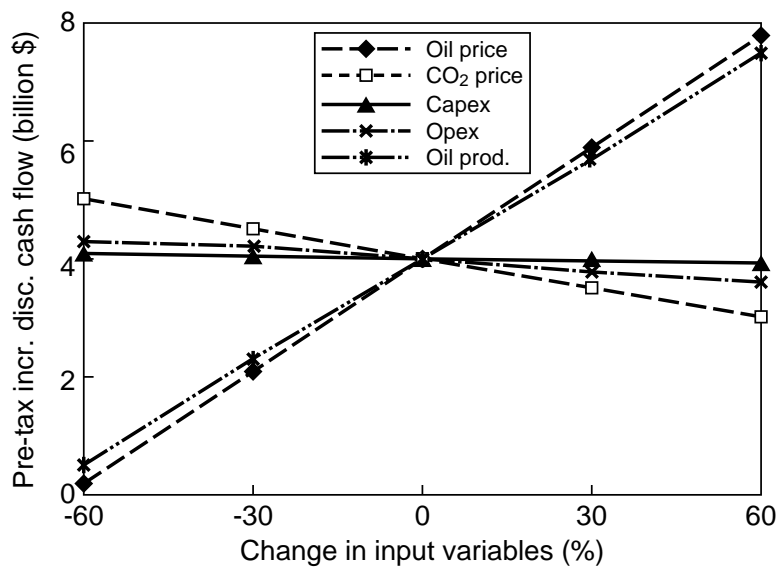

Figure 8

NPV sensitivity, pre-tax, $\mathrm{CO}_{2}$ case.

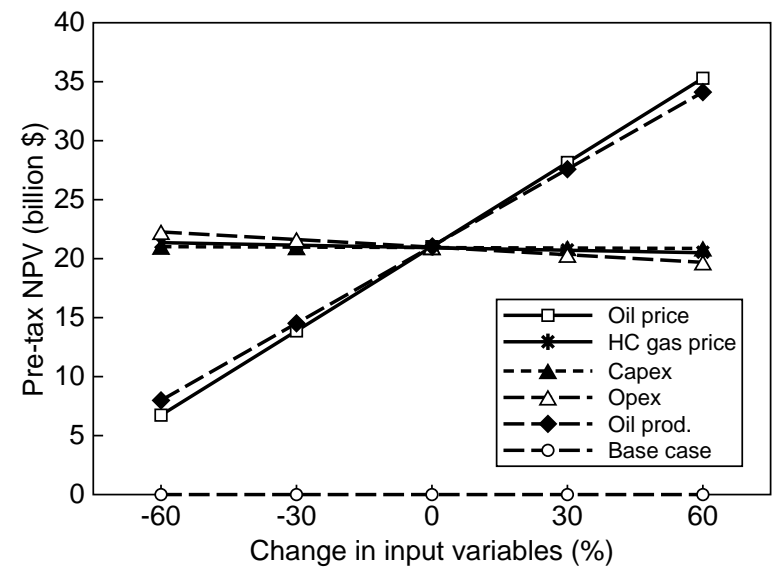

Figure 10

Pre-tax NPV sensitity, hydrocarbon gas.

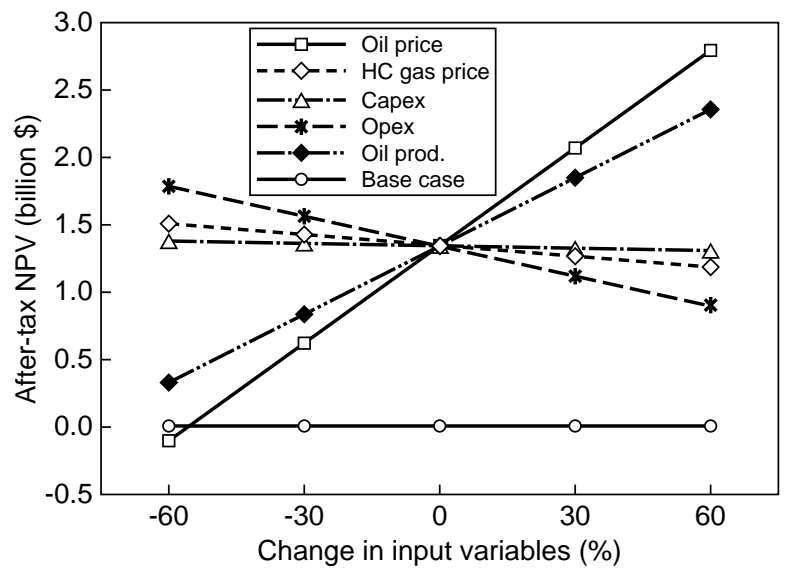

Figure 11

After tax NPV sensitivity, hydrocarbon gas.
Figures. 8, 9, 10 and 11. These curves could be used to study the effect of changing any economic parameter on the net present values.

\subsubsection{General Principles and Premises for EOR}

The main consideration drawn from the cost estimates and the financial analysis reported in this study is that: $\mathrm{CO}_{2}$ is to be used in the Libya as the main EOR solvent gas, the tertiary barrel will cost less some $\$ 7.14$ (in 1996 monies); the financial feasibility of EOR by rich hydrocarbon gas injection (to achieve miscible floods in the reservoirs for higher oil recovery) depends upon:

- the market damned- supply balance for gas;

- the policy adopted for valuing this gas to impute costs to EOR when it is injected into reservoirs. 
All initially miscible gas floods for EOR will inevitably turn immiscible because of the injection geometry and will create secondary gas caps. These gas caps will be blownand the recovered gas sold-without regard to GOR, by treating the former oil reservoir as a gas reservoir and recompilations some of the wells. This aspect should be taken into consideration in most of the reservoir profiles and financial evaluation. The difference is that marketing of the rich hydrocarbon gases as they are first produced or delaying their sale until they are first used for EOR have very different net present value. Where $\mathrm{CO}_{2}$ is the solvent gas, the operating company has the choice of re-cycling the produced gases $\left(\mathrm{CO}_{2}+\right.$ Hydrocarbon gas mixture after $\mathrm{CO}_{2}$ breakthrough) without separation or separating the hydrocarbons for marketing and internal use (of methane as compressor fuel).

\section{CONCLUSIONS}

1 The after tax results indicates improvements in key input variable (e.g., oil price, tax rate, EOR technology) will be required before EOR projects can become economically viable. Given the long-term nature of these projects, the economics may improve over time.

2 The pre-tax results are much more positive for EOR development, although these can vary with the cost of injection gas.

3 On both a pre-tax and after-tax basis, $\mathrm{CO}_{2}$ injection appears to be much more attractive than $\mathrm{HC}$ solvent injection. The cost of the injection gas is one of the key factors affecting the economics of EOR development.

4 The large spread between the pre-tax and after tax results indicates that tax incentives will likely be required before an EOR project can become economically viable on an after-tax basis. As a result, before many of these projects can proceed, a special EOR tax structure will likely be required after-tax situation.

5 The economic results will improve if produced $\mathrm{CO}_{2} / \mathrm{HC}$ gas can be sold for reuse in other areas.

\section{ACKNOWLEDGEMENTS}

We thank John Norton of Waha Oil Co. for valuable discussions on the sensitivity analysis. Special thanks for the Management of Waha Oil Company for permission to publish this work.

\section{REFERENCES}

Bondor, P.L. (1992) Applications of Economic Analysis in EOR Research. Paper SPE 24233, SPE Oil and Gas Economics, Finance and Management Conference, London, England, April, 28-29.

Flanders, W.A. and McGinnis, R.A. (1993) CO2 Economics for Small-to-Medium-Size Fields. Paper SPE 26391, 68th Annual Technical Conference and Exhibition, Houston, Texas, United States, Oct., 3-6.

Final manuscript received in March 2002 